\title{
Giant Cell Glioblastoma
}

National Cancer Institute

\section{Source}

National Cancer Institute. Giant Cell Glioblastoma. NCI Thesaurus. Code C4325.

A rare histological variant of glioblastoma (WHO grade IV) with a predominance of bizarre, multinucleated giant cells, an occasionally abundant stromal reticulin network, and a high frequency of TP53 mutations. (WHO) 